\title{
Moisture content of seeds affects relative biological effectiveness of alpha particles but not protons in thermal neutron exposure
}

\author{
Yasuo Ukai*1), Isao Yamaguchi' ${ }^{1)}$ and Hiroshi Takaki ${ }^{2)}$ \\ 1) Institute of Radiation Breeding, NIAS, MAFF, Hitachi-Ohmiya, Ibaraki 319-2293, Japan \\ 2) Faculty of Agriculture, University of Miyazaki, Gakuen-Kibanadai-Nishi-1-1, Miyazaki 889-2192, Japan
}

\begin{abstract}
The influences of moisture content of barley (Hordeum vulgare L.) seeds which were presoaked for $13 \mathrm{~h}$ and re-dried before irradiation on boron addition effect (BAE) and relative biological effectiveness (RBE) of alpha particles and protons were evaluated. Seeds of normal (10.21\% in embryo), low (2.55\%) and high (28.0\%) moisture content showed different regression of BAE values on the absorbed amount of ${ }^{10} \mathrm{~B}$. The regression coefficient was highest for normal moisture content, followed by low moisture content, and the lowest for high moisture content. RBE of alpha particles also significantly differed between the moisture contents. Seeds of normal, low and high moisture contents showed 46.4, 37.4 and 17.0 of RBE value, respectively. Contrarily, RBE values of protons did not significantly vary with moisture content. It was found that the ratio of RBE of alpha particles between different moisture contents could be expressed by the product of the three ratios, i.e. ratio of sensitivity to gamma-rays, ratio of BAE, and ratio of moisture content. It was concluded that adjustment of moisture of the seeds to normal content (about 10\%) is important to get a high value of both BAE and RBE of alpha particles.
\end{abstract}

Key Words: RBE, boron addition effect, alpha particles, protons, thermal neutrons, moisture content, Hordeum vulgare.

\section{Introduction}

Radiations with high linear energy transfer (LET) are generally more efficient in inducing mutations than are low-LET radiations such as gamma-rays and X-rays. Among the highLET radiations, especially fast and thermal neutrons have been expected to be a useful sources for mutation induction in mutation breeding (Ukai 1986, 2006). Neutron-induced mutants are also used as resources for plant genetics, particularly in functional genomics and reverse genetics (Bruggemann et al. 1996, Li et al. 2001, Li et al. 2002). In the majority of studies of neutrons in plants fast neutrons were the target, and the effects of thermal neutrons have scarcely been investigated (IAEA 1974). Basically, the fast and thermal neutrons differ in their manner of giving energy to irradiated materials. The energy of fast neutrons is chiefly absorbed through elastic collision with hydrogen nuclei. Contrarily, 99 percent of the total energy deposited in plant tissue exposed to thermal neutrons derives from the nuclear capture reactions by boron-10 $\left({ }^{10} \mathrm{~B}\right)$, nitorogen-14 $\left({ }^{14} \mathrm{~N}\right)$ and hydrogen-1 $\left({ }^{1} \mathrm{H}\right)$ (Conger and Giles 1950). Among these isotopes, ${ }^{10} \mathrm{~B}$ and ${ }^{14} \mathrm{~N}$ are attractive from viewpoint of radiobiology and mutation breeding, since they emit heavy particles with high LET, i.e. alpha particles and protons, respectively,

Communicated by T. Nishio

Received December 26, 2008. Accepted March 25, 2009.

*Corresponding author (e-mail: luke154@jcom.home.ne.jp) after capture of thermal neutrons.

A term 'the relative biological effectiveness' (RBE) is used to compare the relative effectiveness of radiations with differing LET values. RBE is defined as the dose of a reference radiation (traditionally of low LET X-rays or ${ }^{60} \mathrm{Co}$ gamma-rays) divided by the dose of radiation under test to produce a given level of damage. The RBE values of thermal neutrons reported in microorganisms and animals are generally low (Davis et al. 1970), and mostly close to unity (Bender 1970). In plant materials, on the other hand, much higher RBE values have been reported. For instance, Conger and Giles (1950) reported an RBE value of 15 for chromosome aberrations in exposure of inflorescence of Tradescantia paludosa to thermal neutrons. Matsumura et al. (1963) found RBE values of 8 to 56 for chromosome aberrations and chlorophyll mutation after irradiation of presoaked seeds of Triticum monococcum with thermal neutrons. Ikushima (1972b) observed an RBE value of 18.0 for seedling height in hexaploid wheat after irradiation of presoaked seeds. Ukai et al. (2009) showed that the RBE value of alpha particles was as high as 55.0 when barley seeds immersed in a solution of different concentrations of ${ }^{10} \mathrm{~B}-$ enriched boric acid and re-dried were exposed to thermal neutrons. The RBE value we obtained was higher than most of those reported by other researchers in plants. The differences in the magnitude of RBE values so far reported may come, at least partly, from the differences in the condition of the materials employed. Most of the experiments on RBE in 
plants have been made using a metabolizing organ of growing plants or presoaked seeds with a high moisture content while we used re-dried seeds which had moisture content almost equal to air-dried resting seeds. We thought that high moisture content and/or metabolizing process are involved in the major causes for the low RBE values recognized in the former experiments.

Ikushima (1972a) reported an RBE value of 11.5 for seedling height in Avena strigosa $(2 \mathrm{n}=14)$ in exposure of dry seeds to $14.1 \mathrm{MeV}$ fast neutrons while much lower RBE values (2.4 to 1.2) in exposure of seeds presoaked for 6 to 48 hours. From this result, he concluded that moisture content of the seeds is one of the major factors modifying RBE values. No similar experiments have so far been carried out for thermal neutrons, as far as the authors are aware.

The present study was undertaken to ascertain whether the change in moisture content of seeds exerts its influence on RBE in thermal neutron exposure. RBE values of alpha particles from ${ }^{10} \mathrm{~B}(\mathrm{n}, \alpha){ }^{7} \mathrm{Li}$ and protons from ${ }^{14} \mathrm{~N}(\mathrm{n}, \mathrm{p}){ }^{14} \mathrm{C}$ were estimated, by using barley seeds which were presoaked in a solution of varying concentrations of ${ }^{10} \mathrm{~B}$-enriched boric acid and re-dried to different moisture contents before neutron and gamma-ray irradiation.

\section{Materials and Methods}

A six-rowed hulled barley variety, Hordeum vulgare L., cv. Chikurin Ibarakil was used as the plant material in all experiments.

\section{Boron enrichment}

Aqueous solutions of different concentrations of ${ }^{10} \mathrm{~B}$ enriched boric acid $\left(\mathrm{H}_{3}{ }^{10} \mathrm{BO}_{3}\right)$ were prepared by using boric acid (Eagle-Picher Industries Inc. Miami, Oklahoma, USA), in which the boron was composed of $91.746 \%{ }^{10} \mathrm{~B}$ and $8.254 \%{ }^{11} \mathrm{~B}$ (weight $\%$ ). A solution of $2040 \mu \mathrm{g} \cdot \mathrm{g}^{-1}$ of natural boric acid (i.e., $\mathrm{H}_{3} \mathrm{BO}_{3}$ with a normal boron isotope ratio, i.e. $19.9 \%{ }^{10} \mathrm{~B}$ and $80.1 \%{ }^{11} \mathrm{~B}$ ) was also included for comparison. Air-dried seeds with $\mathrm{ca}$. 10\% moisture content were immersed in aqueous solutions of $0,100,400$, and $1600 \mu \mathrm{g} \cdot \mathrm{g}^{-1}$ of $\mathrm{H}_{3}{ }^{10} \mathrm{BO}_{3}$ or $2040 \mu \mathrm{g} \cdot \mathrm{g}^{-1}$ of $\mathrm{H}_{3} \mathrm{BO}_{3}$ in a $500 \mathrm{ml}$ glass beaker for $13 \mathrm{~h}$ at $20 \pm 1^{\circ} \mathrm{C}$. Each boron treatment used 2400 seeds. The seeds were then washed with distilled and deionized water for a few minutes, and the surface water was blotted from the seeds. Seeds were then dried again by exposure of seeds to a current of warm $\left(31 \pm 2^{\circ} \mathrm{C}\right)$, dry air for $16 \mathrm{~h}$, after which moisture content was around $10 \%$. Every seed was given a characteristic mark with a marker pen on the seed coat which shows the boric acid concentration in the aqueous solution. Then the twenty seeds from each of the five different concentrations of boric acid for a moisture content were mixed and a total of 100 seeds were put in a single paper bag; 120 bags of the same constitution of seeds were prepared.

\section{Preparation of seeds with different moisture contents}

The 120 bags were divided into three groups and the seeds in different groups were pretreated so as to get different moisture contents. A group of bags with the mouth open was kept over a saturated $\mathrm{NaClO}_{3}$ solution and a second group over $\mathrm{P}_{2} \mathrm{O}_{5}$ in a desiccator for one month, which gave seeds $10.21 \%$ and $2.55 \% \mathrm{w} / \mathrm{w}$ of moisture contents of embryos, respectively. The third group was immersed in deionized water for 45 minutes at room temperatures (about $22^{\circ} \mathrm{C}$ ) just before irradiation, and the surface water was blotted from the seeds, resulting in the seeds with moisture content of embryos of $28.00 \%$. The seeds of each batch so prepared were sealed in a small plastic bag to avoid possible change of moisture content of seeds before and during irradiation with thermal neutrons or gamma-rays.

\section{Boron and nitrogen content}

The boron contents of the embryo of the seeds soaked in 100,400 and $1600 \mu \mathrm{g} \cdot \mathrm{g}^{-1}$ of $\mathrm{H}_{3}{ }^{10} \mathrm{BO}_{3}$ for $13 \mathrm{~h}$ shown in a previous paper (Ukai et al. 2009) were adopted as the contents on a dry matter basis for the corresponding boric acid concentrations in the present experiment. The boron content of the embryo of the seeds soaked in $2040 \mu \mathrm{g} \cdot \mathrm{g}^{-1}$ of $\mathrm{H}_{3} \mathrm{BO}_{3}$ was calculated from the value in $1600 \mu \mathrm{g} \cdot \mathrm{g}^{-1}$ of $\mathrm{H}_{3}{ }^{10} \mathrm{BO}_{3}$, by 7.1 $\times 0.199+(188.5 / 1600) \times 2040 \times 0.199=45.28$, where 7.1 , 188.5 and 0.199 are total boron content of the resting seeds, the amount of absorbed boron for $1600 \mu \mathrm{g} \cdot \mathrm{g}^{-1}$, and the existing ratio of ${ }^{10} \mathrm{~B}$ in natural boron, respectively. Furthermore, nitrogen content of the embryo of resting seeds in the previous experiment was adopted here.

\section{Thermal neutron and gamma-ray irradiation}

Thermal neutron exposures were carried out at the heavy water $\left(\mathrm{D}_{2} \mathrm{O}\right)$ facility of Kyoto University Reactor, operating at 5MW. Twenty seeds with two replications were used for each combination of boric acid concentration and neutron dose. Seeds for low, normal and high moisture contents were sealed separately in a thin polyethylene bag, placed in the top part of a plastic (polypropylene) cylinder with $6 \mathrm{~cm}$ in diameter and $12 \mathrm{~cm}$ in length. During the exposure, the cylinder was carefully positioned at the center of the thermal neutron field on the bismuth wall of the heavy water facility through irradiation tube. A bag of the seeds for low, normal and high moisture contents were placed in the top, medium, and bottom layers, respectively, and the received fluxes of thermal neutrons were 5.93, 5.32 and $4.70 \times 10^{9} \mathrm{n} \cdot \mathrm{cm}^{-2} \mathrm{sec}^{-1}$ and the dose rates of contaminating gamma-rays were $6.04,7.58$ and $7.78 \mathrm{~Gy}$ per $h$, respectively. The thermal neutron exposure time ranged from 1 to $150 \mathrm{~min}$. For the gamma-ray irradiation, we used a source of ${ }^{60} \mathrm{Co}$ in the gamma-room of the Institute of Radiation Breeding, National Institute of Agrobiological Sciences, Ministry of Agriculture, Forestry and Fishery, HitachiOhmiya, Ibaraki, at a dose rate of $76.8 \mathrm{~Gy} / \mathrm{hr}$.

Thermal neutron flux was measured by the activation of gold-foil (about 5mg in weight), and the absorbed dose of contaminating gamma-rays inherent in the thermal neutron 
First leaf length (fraction of the non-irradiated control)

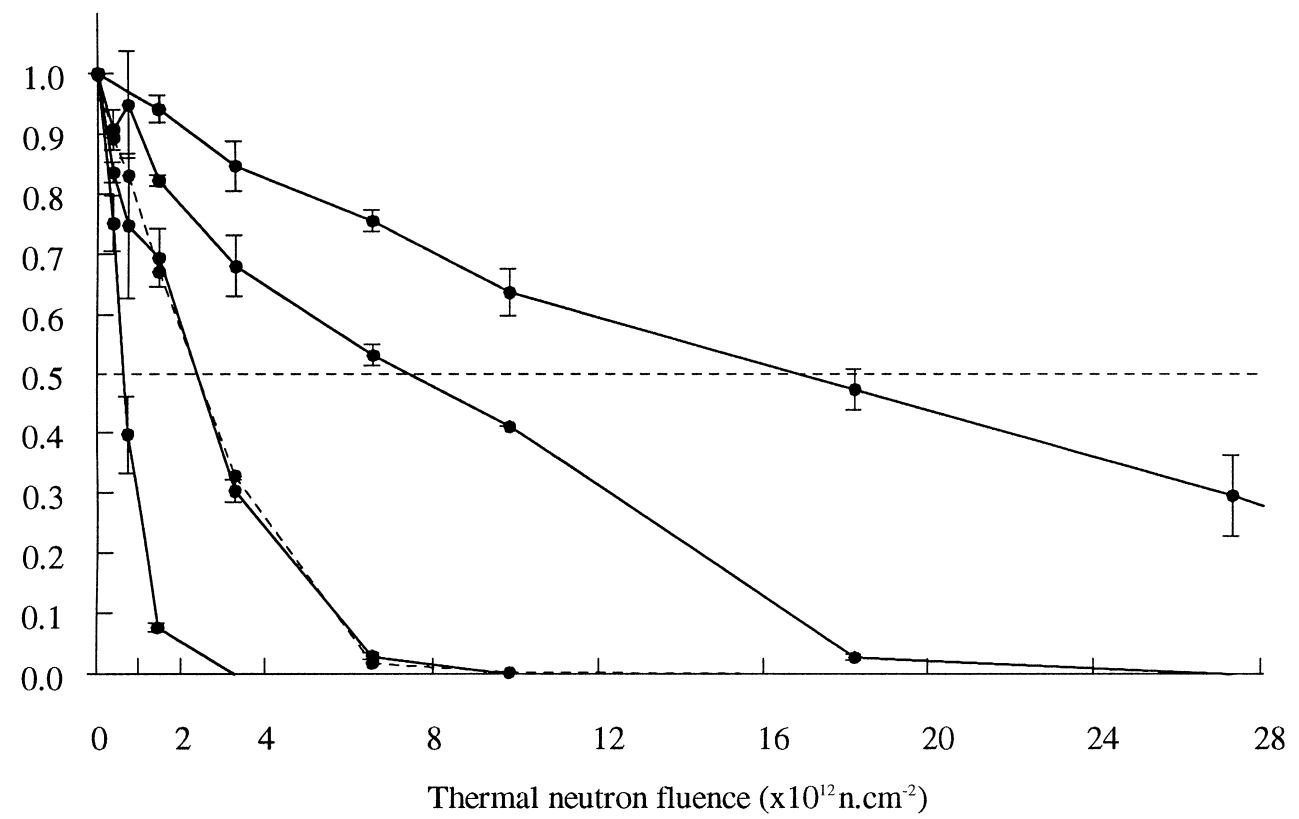

Fig. 1. Dose-response curves for first leaf length as a fraction of the value of the non-irradiated control after thermal neutron exposure of seeds presoaked in aqueous solution of different concentrations $\left(0-1600 \mu \mathrm{g} \cdot \mathrm{g}^{-1}\right)$ of boric acid for $13 \mathrm{~h}$ and re-dried. From right to left, $0 \mu \mathrm{g} \cdot \mathrm{g}^{-1}, 100 \mu \mathrm{g} \cdot \mathrm{g}^{-1}$, $400 \mu \mathrm{g} \cdot \mathrm{g}^{-1}, 1600 \mu \mathrm{g} \cdot \mathrm{g}^{-1}$ of ${ }^{10} \mathrm{~B}$-enriched boric acid (solid lines), and $2040 \mu \mathrm{g} \cdot \mathrm{g}^{-1}$ natural boric acid (dotted line)

irradiation was determined by using a thermo-luminescence dosimeter with a polyethylene-shielded $\mathrm{Mg}_{2} \mathrm{SiO}_{4}$ element. A piece of the gold-foil and a tube of $\mathrm{Mg}_{2} \mathrm{SiO}_{4}$ powder were placed in each of the seed bags exposed to the neutrons.

\section{Measurement of seedling growth}

Twenty seeds (with two replications) for each combination of concentration of boric acid, moisture content, and irradiation dose were sown in vermiculate in wooden boxes and allowed to germinate at about $20^{\circ} \mathrm{C}$ in a plastic greenhouse in an isolated field. The first leaf length (=the length of leaf blade plus leaf sheath) of the $M_{1}$ seedlings was measured 14 days after sowing. Based on the line graph in which the observed points are connected with lines, the dose required to give 50 per cent inhibition of seedling growth (half-reduction dose $\mathrm{D}_{50}$ ) was estimated, and adopted as a measure of radiation effect (see Fig. 1).

\section{Results}

\section{Sensitivity to neutrons and gamma-rays}

Sensitivity to thermal neutrons greatly increased with increasing concentrations of boric acid in which the seeds were immersed before neutron exposure (Fig. 1). Radiosensitivity to thermal neutrons and gamma-rays as expressed by half-reduction dose for the first leaf length of the $\mathrm{M}_{1}$ seedlings $\left(D_{50 \mathrm{~g}}, D_{50 \mathrm{n}}\right)$ are shown in Table 1 . The values of $\mathrm{D}_{50 \mathrm{~g}}$ for $0 \mu \mathrm{g} \cdot \mathrm{g}^{-1}$ solution were 353,365 , and $236 \mathrm{~Gy}$ and the values of $D_{50 \mathrm{n}}$ were $16.92,17.08$ and $16.07 \times 10^{12} \mathrm{n} \cdot \mathrm{cm}^{-2}$ for normal, low and high moisture contents, respectively. There were little differences in the sensitivity to gamma-rays between low and normal moisture content, whereas the $\mathrm{D}_{50 \mathrm{~g}}$ value for seeds with high moisture content was lower than those of the other moisture contents. No significant differences were recognized in the values of $\mathrm{D}_{50 \mathrm{n}}$ for $0 \mu \mathrm{g} \cdot \mathrm{g}^{-1}$ solution between the moisture contents investigated $(\mathrm{P}>0.05)$.

In all the moisture contents studied, $\mathrm{D}_{50 \mathrm{n}}$ decreased with increase of the concentrations of ${ }^{10} \mathrm{~B}$-enriched boric acid whereas $D_{50 \mathrm{~g}}$ showed no systematic change with the concentration in all moisture contents.

\section{Boron addition effect (BAE)}

BAE was expressed as the ratio of $D_{50 \mathrm{n}}$ of $0 \mu \mathrm{g} \cdot \mathrm{g}^{-1}$ $\left(\mathrm{D}_{50 \mathrm{n}}{ }^{(0)}\right)$ to $\mathrm{D}_{50 \mathrm{n}}$ for a given concentration of boric acid $\left(\mathrm{D}_{50 \mathrm{n}}{ }^{(1)}\right)$. Namely,

$$
\mathrm{BAE}=\mathrm{D}_{50 \mathrm{n}}{ }^{(0)} / \mathrm{D}_{50 \mathrm{n}}{ }^{(1)}
$$

BAE increased with increasing concentration of ${ }^{10} \mathrm{~B}$-enriched boric acid. In the highest concentration $\left(1600 \mu \mathrm{g} \cdot \mathrm{g}^{-1}\right)$ of $\mathrm{H}_{3}{ }^{10} \mathrm{BO}_{3}$ solution, $\mathrm{BAE}$ values were $29.44,29.24$ and 15.83 , for normal, low and high moisture content, respectively. Natural boric acid also proved effective, reducing $\mathrm{D}_{50 \mathrm{n}}$ by a magnitude nearly equal to that of $400 \mu \mathrm{g} \cdot \mathrm{g}^{-1}$ of ${ }^{10} \mathrm{~B}$-enriched boric acid. A solution of $2040 \mu \mathrm{g} \cdot \mathrm{g}^{-1}$ of natural boric acid has the content of ${ }^{10} \mathrm{~B}$ equal to the content in $2040 \times 0.199$ / $0.91746=442 \mu \mathrm{g} \cdot \mathrm{g}^{-1}{ }^{10} \mathrm{~B}$-enriched boric acid solution.

The amounts of ${ }^{10} \mathrm{~B}$ absorbed by the embryo per $\mathrm{g}$ of tissue were calculated from the contents of ${ }^{10} \mathrm{~B}$ in each combination of moisture content and boric acid concentration shown in Table 1. The amounts differed with moisture content of 
Table 1. Sensitivity to gamma-rays $\left(D_{50 \mathrm{~g}}\right)$, and thermal neutrons $\left(\mathrm{D}_{50 \mathrm{n}}\right)$, boron addition effect (BAE) and the absorbed dose of boron $\left(d_{\mathrm{B}}\right)$

\begin{tabular}{|c|c|c|c|c|c|c|}
\hline $\begin{array}{l}\text { Moisture } \\
\text { content }\end{array}$ & $\begin{array}{c}\text { Concentr. } \\
\text { boric acid } \\
\mu \mathrm{g} \cdot \mathrm{g}^{-1}\end{array}$ & $\mathrm{D}_{50 \mathrm{~g}}{ }^{a}$ & $\begin{array}{l}\mathrm{D}_{50 \mathrm{n}}{ }^{a} \\
\times 10^{12} \\
\mathrm{n} \cdot \mathrm{cm}^{-2} \\
\end{array}$ & $\mathrm{BAE}^{b}$ & $\begin{array}{c}\text { Content } \\
\text { of }{ }^{10} \mathrm{~B}^{c} \\
10^{-6} \mu \mathrm{g} \cdot \mathrm{g}^{-1}\end{array}$ & $\begin{array}{c}d_{\mathrm{B}}{ }^{d} \\
\times 10^{-12} \\
\mathrm{~Gy} \cdot \mathrm{n}^{-1} \cdot \mathrm{cm}\end{array}$ \\
\hline \multirow{5}{*}{ Normal } & 0 & 353 & 16.92 & 1 & 1.27 & 0.109 \\
\hline & $100 \mathrm{H}_{3}{ }^{10} \mathrm{BO}_{3}$ & 419 & 7.18 & 2.36 & 10.91 & 0.935 \\
\hline & $400 \mathrm{H}_{3}{ }^{10} \mathrm{BO}_{3}$ & 398 & 2.17 & 7.79 & 43.45 & 3.723 \\
\hline & $1600 \mathrm{H}_{3}{ }^{10} \mathrm{BO}_{3}$ & 383 & 0.575 & 29.44 & 156.55 & 13.413 \\
\hline & $2040 \mathrm{H}_{3} \mathrm{BO}_{3}$ & 383 & 1.98 & 8.55 & $44.21^{e}$ & 3.788 \\
\hline \multirow[t]{5}{*}{ Low } & 0 & 365 & 17.08 & 1 & 1.38 & 0.118 \\
\hline & $100 \mathrm{H}_{3}{ }^{10} \mathrm{BO}_{3}$ & 383 & 7.54 & 2.26 & 11.84 & 1.014 \\
\hline & $400 \mathrm{H}_{3}{ }^{10} \mathrm{BO}_{3}$ & 353 & 2.35 & 7.27 & 47.15 & 4.040 \\
\hline & $1600 \mathrm{H}_{3}{ }^{10} \mathrm{BO}_{3}$ & 398 & 0.605 & 28.24 & 169.91 & 14.558 \\
\hline & $2040 \mathrm{H}_{3} \mathrm{BO}_{3}$ & 413 & 2.28 & 7.50 & $47.98^{e}$ & 4.111 \\
\hline \multirow[t]{5}{*}{ High } & 0 & 236 & 16.07 & 1 & 1.02 & 0.087 \\
\hline & $100 \mathrm{H}_{3}{ }^{10} \mathrm{BO}_{3}$ & 221 & 9.17 & 1.75 & 8.75 & 0.749 \\
\hline & $400 \mathrm{H}_{3}{ }^{10} \mathrm{BO}_{3}$ & 236 & 3.22 & 4.99 & 34.84 & 2.985 \\
\hline & $1600 \mathrm{H}_{3}{ }^{10} \mathrm{BO}_{3}$ & 206 & 1.02 & 15.83 & 125.54 & 10.756 \\
\hline & $2040 \mathrm{H}_{3} \mathrm{BO}_{3}$ & 221 & 3.55 & 4.53 & $35.45^{e}$ & 3.038 \\
\hline
\end{tabular}

${ }^{a} \mathrm{D}_{50 \mathrm{~g}}$ : Half-reduction dose for gamma-rays in Gy

$\mathrm{D}_{50 \mathrm{n}}$ : Half-reduction dose for thermal neutrons in $\mathrm{n} \cdot \mathrm{cm}^{-2}$

${ }^{b}$ BAE: Boron addition effect. For instance, BAE for $100 \mu \mathrm{g} \cdot \mathrm{g}^{-1}=\mathrm{D}_{50 \mathrm{n}}$ for $0 \mu \mathrm{g} \cdot \mathrm{g}^{-1} / \mathrm{D}_{50 \mathrm{n}}$ for $100 \mu \mathrm{g} \cdot \mathrm{g}^{-1}$.

${ }^{c}$ Content per $\mathrm{g}$ of tissue (not on a dry matter basis). For instance, content of ${ }^{10} \mathrm{~B}$ for $100 \mathrm{ppm}=\left(\right.$ Total boron $\left({ }^{10} \mathrm{~B}+{ }^{11} \mathrm{~B}\right)$ content for $0 \mathrm{ppm} \times$ $0.199+$ Total boron content absorbed for $100 \mathrm{ppm} \times 0.91746) \times(1-\mathrm{w})$ where $\mathrm{w}$ is moisture content of seeds.

${ }^{d} d_{\mathrm{B}}$ : the absorbed dose of boron. per $1 \mathrm{n} \cdot \mathrm{cm}^{-2}$ of fluence of thermal neutrons

${ }^{e}$ Calculated from the value of $1600 \mu \mathrm{g} \cdot \mathrm{g}^{-1}$ of $\mathrm{H}_{3}{ }^{10} \mathrm{BO}_{3}$

the seeds. When BAE was plotted as a function of the amount of ${ }^{10} \mathrm{~B}$ (Fig. 2), a linear relationship was found between the two for each moisture content as follows;

Normal moisture content: $Y=0.204 X-0.089$

Low moisture content: $\quad Y=0.182 X-0.236$

High moisture content: $\quad Y=0.132 X+0.563$

where $X$ is the amount of absorbed ${ }^{10} \mathrm{~B}$ and $Y$ is BAE. All the regressions were significant at $1 \%$ level. Since $\mathrm{BAE}(\mathrm{Y})$ is 1 when the amount of absorbed ${ }^{10} \mathrm{~B}(\mathrm{X})$ is 0 , the regression line should pass through the point $(0,1)$. In fact, the $99 \%$ confidence intervals of the intercepts of the regression lines for normal, low and high moisture contents were $(-2.273$, $2.095),(-3.139,2.667)$ and $(-1.118,2.244)$, respectively. Thus, the intervals for all the regression lines included 1 , so the observed values were fitted to a model $Y=\beta X+1$. The results were as follows;

$\begin{array}{ll}\text { Normal moisture content: } & Y=0.195 X+1 \\ \text { Low moisture content: } & Y=0.171 X+1 \\ \text { High moisture content: } & Y=0.127 X+1\end{array}$

The regression coefficient was highest for normal moisture content, followed by low moisture content, and the lowest for high moisture content.
BAE

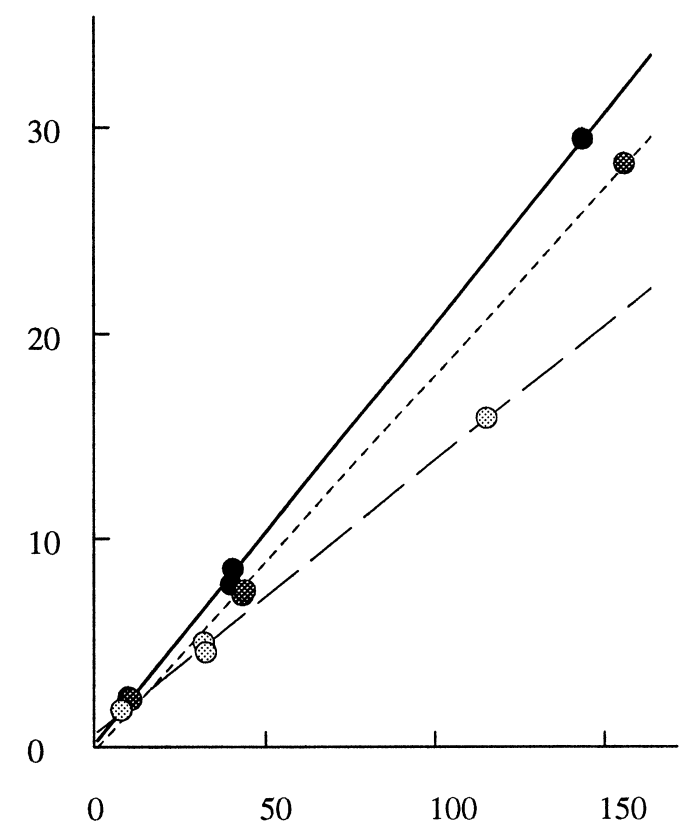

Amount of ${ }^{10} \mathrm{~B}$ absorbed per $\mathrm{g}$ of tissue $\left(10^{-6} \mathrm{~g} \cdot \mathrm{g}^{-1}\right)$

Fig. 2. Boron addition effect (BAE) as a function of ${ }^{10} \mathrm{~B}$ absorbed by the embryo (per $\mathrm{g}$ of tissue). Solid, gray and light gray circles represent normal (10.21\%), low (2.55\%) and high (28.0\%) moisture content, respectively.

\section{Absorbed dose by ${ }^{10} \mathrm{~B}$}

We calculated the specific doses absorbed by ${ }^{10} \mathrm{~B},{ }^{14} \mathrm{~N}$ and ${ }^{1} \mathrm{H}$ by using the formula of Conger and Giles (1950) and Archambeau (1971);

$$
d=1.602 \times 10^{-10} N_{u} \sigma E c
$$

where

$1.602 \times 10^{-10}$ is the conversion factor from $\mathrm{MeV}$ to $\mathrm{Gy}$,

$d$ is the absorbed dose per fluence of thermal neutrons $\left(\mathrm{Gy} \cdot \mathrm{nth}^{-1} \cdot \mathrm{cm}^{2}\right)$,

$N_{u}$ is the number of capture nucleus per $\mathrm{g}$ of tissue $\left(\mathrm{g}^{-1}\right)$, $\sigma$ is the thermal neutron capture cross-section of the target element in $\mathrm{cm}^{2}$ (=value in barns $\times 10^{-24}$ )

$E$ is the energy of the emitted radiation ( $\mathrm{MeV}$ )

$c$ is the fraction of the liberated energy absorbed by the tissue. The absorbed dose represents the energy absorbed per gram of an irradiated material. The constant $1.602 \times 10^{-10}$ is the factor used to convert the absorbed dose $\left(\mathrm{MeV} \cdot \mathrm{g}^{-1}\right)$ into Gy $\left(\mathrm{Gy} \cdot \mathrm{g} \cdot \mathrm{MeV}^{-1}\right) \cdot N_{u}$ is a function of $w, t, R, L$, and $A$, as follows;

$N_{\mathrm{u}}=(1-w) t R L / A$ for boron and nitrogen,

$N_{\mathrm{u}}=(1-w) t R L / A+w(2 / 18.00436) R L / A$ for hydrogen, (4b)

where $\mathrm{w}$ is the moisture content of seeds, $t$ is the content of the capture element per tissue on a dry matter basis $\left(\mathrm{g} \cdot \mathrm{g}^{-1}\right), R$ is the existing ratio of the reacting isotope of the element, $L$ is the Avogadro constant $\left(6.02214199 \times 10^{23}\right)$ and $A$ is the atomic weight $\left(\mathrm{g} \cdot \mathrm{mol}^{-1}\right)$ and 18.00436 is the molecular 
Table 2. Physical values adopted for the calculation of the number of nucleus per tissue

\begin{tabular}{lccc}
\hline \hline & ${ }^{10} \mathrm{~B}$ & ${ }^{14} \mathrm{~N}$ & ${ }^{1} \mathrm{H}$ \\
\hline R: Existing ratio & 0.199 & 0.99632 & 0.999885 \\
A: Atom weight & 10 & 14 & 1 \\
$\sigma:$ Capture cross section (barn) & 3838 & 1.84 & 0.332 \\
$\quad\left(\times 10^{-24} \mathrm{~cm}^{2}\right)$ & & & \\
E: Energy of the radiation (MeV) & 2.314 & 0.62 & 2.23 \\
c: fraction & 1.0 & 1.0 & 0.02 \\
\hline
\end{tabular}

weight of ${ }^{1} \mathrm{H}_{2} \mathrm{O}$. The values for $\sigma, E, c, A$ and $R$ of the three isotopes ${ }^{10} \mathrm{~B},{ }^{14} \mathrm{~N}$, and ${ }^{1} \mathrm{H}$ that were adopted are shown in Table 2. The contents of total boron on a dry matter basis $\left(7.1,18.8,58.3,195.6 \mu \mathrm{g} \cdot \mathrm{g}^{-1}\right)$ in the embryo of seeds presoaked in $0,100,400$ and $1600 \mu \mathrm{g} \cdot \mathrm{g}^{-1}$ of ${ }^{10} \mathrm{~B}$-enriched boric acid solution and the contents of ${ }^{14} \mathrm{~N}$ and ${ }^{1} \mathrm{H}$ in resting seeds were shown in a previous paper (Ukai et al. 2009). We adopted these values as values of $t$ for ${ }^{10} \mathrm{~B},{ }^{14} \mathrm{~N}$, and ${ }^{1} \mathrm{H}$ in this experiment, too. The absorbed doses of boron $\left(d_{\mathrm{B}}\right)$ were calculated according to Eqs.(3) and (4a), for different concentrations of boric acid (Table 1).

\section{Estimation of RBE of alpha particles}

As was previously shown (Ukai et al. 2009), the following relationship holds;

$$
\begin{aligned}
\mathrm{D}_{50 \mathrm{~g}} & =D_{50 \mathrm{n}}\left(\delta+d_{\mathrm{H}}+e_{\mathrm{N}} d_{\mathrm{N}}+e_{\mathrm{B}} d_{\mathrm{B}}\right) \\
& =D_{50 \mathrm{n}}\left(K+e_{\mathrm{B}} d_{\mathrm{B}}\right)\left(K=\delta+d_{\mathrm{H}}+e_{\mathrm{N}} d_{\mathrm{N}}\right)
\end{aligned}
$$

where

$D_{50 \mathrm{~g}}$ is the half-reduction dose in gamma-ray exposure (in Gy), $D_{50 \mathrm{n}}$ is the half-reduction dose in thermal neutron exposure (in fluence, $\mathrm{n} \cdot \mathrm{cm}^{-2}$ )

$\delta$ is the dose of contaminating gamma-rays (in Gy per fluence of neutrons),

$d_{\mathrm{H}}, d_{\mathrm{N}}$, and $d_{\mathrm{B}}$ are the neutron energies absorbed by ${ }^{1} \mathrm{H},{ }^{14} \mathrm{~N}$, and ${ }^{10} \mathrm{~B}$, respectively (in Gy per fluence of neutrons),

$e_{\mathrm{N}}$ and $e_{\mathrm{B}}$ is the RBE values of protons from a capture reaction ${ }^{14} \mathrm{~N}(\mathrm{n}, \mathrm{p}){ }^{14} \mathrm{C}$, and alpha particles from ${ }^{10} \mathrm{~B}(\mathrm{n}, \alpha){ }^{7} \mathrm{Li}$, respectively. The RBE of gamma-rays from ${ }^{1} \mathrm{H}(\mathrm{n}, \gamma)^{2} \mathrm{H}$ and contaminating gamma-rays were assumed to equal 1 .

$\delta$ can be obtained by dosimetry. $d_{\mathrm{N}}$ and $d_{\mathrm{H}}$ are calculated according to Eq.(3) on the basis of the number of nucleus per $\mathrm{g}$ of tissue $\left(N_{\mathrm{u}}\right)$ which is obtained by using Eqs.(4a) or (4b), respectively (Table 3 ). The contents of nitrogen and hydrogen differs with moisture content, but do not change during the addition of boron, and hence the absorbed dose of nitrogen $\left(d_{\mathrm{N}}\right)$ and hydrogen $\left(d_{\mathrm{H}}\right)$ are constant with concentrations of boric acid.

Letting prefix (0) and (1) for $D_{50 \mathrm{~g}}, D_{50 \mathrm{n}}, d_{\mathrm{B}}$ stand for the treatment with ${ }^{10} \mathrm{~B}$-non-enriched $\left(0 \mu \mathrm{g} \cdot \mathrm{g}^{-1}\right)$ and an enriched solution, respectively, the following relation is obtained from Eq.(5),

$$
e_{\mathrm{B}}=\left(\left(D_{50 \mathrm{~g}}{ }^{(1)} / D_{50 \mathrm{n}}{ }^{(1)}\right)-\left(D_{50 \mathrm{~g}}{ }^{(0)} / D_{50 \mathrm{n}}{ }^{(0)}\right)\right) /\left(d_{\mathrm{B}}{ }^{(1)}-d_{\mathrm{B}}{ }^{(0)}\right) \text {. }
$$

RBE values of alpha particles $\left(e_{\mathrm{B}}\right)$ could be estimated ac-
Table 3. Dose of contaminating gamma-rays $(\delta)$, and the absorbed

\begin{tabular}{|c|c|c|c|c|c|c|}
\hline & \multirow{3}{*}{$\begin{array}{c}\text { Moisture } \\
\text { content }^{a} \\
\%\end{array}$} & \multirow{3}{*}{$\begin{array}{c}\delta^{b} \\
\times 10^{-12} \\
\mathrm{~Gy} \cdot \mathrm{n}^{-1} \cdot \mathrm{cm}^{2}\end{array}$} & \multicolumn{2}{|c|}{$\begin{array}{l}\text { Content per } g \text { of } \\
\text { tissue }\end{array}$} & \multirow{2}{*}{$\begin{array}{c}d_{\mathrm{N}} \\
\times 10^{-12}\end{array}$} & \multirow{2}{*}{$\begin{array}{c}d_{\mathrm{H}} \\
\times 10^{-12}\end{array}$} \\
\hline & & & ${ }^{14} \mathrm{~N}$ & ${ }^{1} \mathrm{H}^{c}$ & & \\
\hline & & & \multicolumn{2}{|c|}{$\times 10^{-3} \mathrm{~g} \cdot \mathrm{g}^{-1}$} & \multicolumn{2}{|c|}{$\mathrm{Gy} \cdot \mathrm{n}^{-1} \cdot \mathrm{cm}^{2} \mathrm{~Gy} \cdot \mathrm{n}^{-1} \cdot \mathrm{cm}^{2}$} \\
\hline Normal & 0.1021 & 0.396 & 49.4 & 74.2 & 0.3882 & 0.1060 \\
\hline Low & 0.0255 & 0.283 & 53.6 & 71.0 & 0.4213 & 0.1015 \\
\hline High & 0.2800 & 0.460 & 39.6 & 81.5 & 0.3113 & 0.1164 \\
\hline
\end{tabular}
dose of nitrogen $\left(d_{\mathrm{N}}\right)$ and hydrogen $\left(d_{\mathrm{H}}\right)$ per fluence of thermal neutrons in the embryo

${ }^{a}$ Moisture content (w/w) of the embryo of seeds

${ }^{b}$ Since the seeds of different moisture contents were placed in different layers during thermal neutron irradiation, doses of contaminating gamma-rays varied between moisture contents.

${ }^{c}$ Content of ${ }^{1} \mathrm{H}$ on a dry matter basis was estimated to be $70 \times 10^{-3} \mathrm{~g} \cdot \mathrm{g}^{-1}$, from the data of Altman and Ditmer (1972).

cording to this equation for different concentrations of boric acid solution. The results are summarized in Table 4. Mean values of $e_{\mathrm{B}}$ were 46.4, 37.4 and 17.0 for normal, low and high moisture contents, respectively. Normal moisture content gave the highest RBE and both decrease and increase from the normal content lowered RBE of alpha particles. Analysis of variance for a two-factor experiment without replication on RBE values revealed that the effect of moisture content was significant at $1 \%$ level, but the effect of boric acid concentration was insignificant. Tukey's multiple comparison showed that RBE for high moisture content was lower than that of normal moisture content at $1 \%$ level, but that the difference in RBE between low and normal moisture contents was insignificant.

\section{Estimation of RBE of protons}

Putting the value of $e_{\mathrm{B}}$ so estimated into Eq.(5) the value of $\mathrm{K}$ and hence the value of $e_{\mathrm{N}}$, RBE of protons, could be obtained as shown in Table 4. Mean values of $e_{\mathrm{N}}$ were 38.2, 38.3 and 40.0 for normal, low and high moisture contents, respectively. Contrary to $e_{\mathrm{B}}$ values, $e_{\mathrm{N}}$ values did not much vary with moisture content. Analysis of variance revealed that the effect of moisture content and the effect of boric acid concentration were both insignificant.

\section{Discussion}

Sensitivity to gamma-rays and thermal neutrons after redrying of pre-soaked seeds

It has been shown in barley (Caldecott 1955a, 1955b, Ehrenberg 1955a, 1955b), rice (Myttenaere et al. 1965, Kawai and Sato 1966, Ukai 1969) and other crops (Katayama and Nagamatsu 1966) that, in the range of 2 to $25 \%$ of moisture content, seeds with an intermediate moisture content are most resistant to gamma-rays or X-rays and the radiosensitivity of seeds increased with decreasing or increasing moisture content. As shown in Table $1, \mathrm{D}_{50 \mathrm{~g}}$ for $0 \mu \mathrm{g} \cdot \mathrm{g}^{-1}\left({ }^{10} \mathrm{~B}\right.$ non-enriched) solution was lower in high moisture content 
Table 4. RBE of alpha particles and protons

\begin{tabular}{llcccc}
\hline \hline $\begin{array}{l}\text { Moisture } \\
\text { content }\end{array}$ & $\begin{array}{c}\text { Concentr. } \\
\text { boric acid } \\
\mu \mathrm{g} \cdot \mathrm{g}^{-1}\end{array}$ & $e_{\mathrm{B}}{ }^{a}$ & $\begin{array}{c}K^{b} \\
\times 10^{-12} \\
\mathrm{~Gy} / \mathrm{n} / \mathrm{cm}^{2}\end{array}$ & $\begin{array}{c}{ }^{10} \mathrm{~B} \\
\text { contribution } \\
\%\end{array}$ & $e_{\mathrm{N}}{ }^{a}$ \\
\hline Normal & $100 \mathrm{H}_{3}{ }^{10} \mathrm{BO}_{3}$ & 45.4 & 15.90 & 72.7 & 39.7 \\
& $400 \mathrm{H}_{3}{ }^{10} \mathrm{BO}_{3}$ & 44.9 & 15.95 & 91.3 & 39.8 \\
& $1600 \mathrm{H}_{3}{ }^{10} \mathrm{BO}_{3}$ & 48.4 & 15.57 & 97.7 & 38.8 \\
& $2040 \mathrm{H}_{3} \mathrm{BO}_{3}$ & 46.9 & 15.74 & 91.9 & 39.3 \\
& Mean & 46.4 & 15.79 & & 39.4 \\
& & & & & \\
& $100 \mathrm{H}_{3}{ }^{10} \mathrm{BO}_{3}$ & 32.8 & 17.47 & 65.6 & 40.6 \\
& $400 \mathrm{H}_{3}{ }^{10} \mathrm{BO}_{3}$ & 32.8 & 17.47 & 88.4 & 40.6 \\
& $1600 \mathrm{H}_{3}{ }^{10} \mathrm{BO}_{3}$ & 44.0 & 16.15 & 97.5 & 37.4 \\
& $2040 \mathrm{H}_{3} \mathrm{BO}_{3}$ & 40.0 & 16.63 & 90.8 & 38.6 \\
& $\mathrm{Mean}^{\text {High }}$ & 37.4 & 16.93 & & 39.3 \\
& $100 \mathrm{H}_{3}{ }^{10} \mathrm{BO}_{3}$ & 14.2 & 13.42 & 44.2 & 41.3 \\
& $400 \mathrm{H}_{3}{ }^{10} \mathrm{BO}_{3}$ & 20.2 & 12.90 & 82.4 & 39.6 \\
& $1600 \mathrm{H}_{3}{ }^{10} \mathrm{BO}_{3}$ & 17.6 & 13.12 & 93.5 & 40.3 \\
& $2040 \mathrm{H}_{3} \mathrm{BO}_{3}$ & 16.1 & 13.25 & 78.7 & 40.7 \\
& $\mathrm{Mean}$ & 17.0 & 13.17 & & 40.5 \\
\hline
\end{tabular}

${ }^{a} e_{B}$ and $e_{\mathrm{N}}$ : RBE of alpha particles and protons, respectively.

${ }^{b} K$ : Total of the residual effects due to the reactions other than ${ }^{10} \mathrm{~B}(\mathrm{n}, \alpha){ }^{7} \mathrm{Li}\left(K=\delta+d_{\mathrm{H}}+e_{\mathrm{N}} d_{\mathrm{N}}\right)$.

than in normal moisture content, suggesting the increase of sensitivity to gamma-rays with increasing moisture content of re-dried seeds. On the other hand, unexpectedly, there was no clear difference in $\mathrm{D}_{50 \mathrm{~g}}$ between normal and low moisture contents. The reason for this is not clear.

$\mathrm{D}_{50 \mathrm{n}}$ for $0 \mu \mathrm{g} \cdot \mathrm{g}^{-1}$ solution showed little or no variation with moisture content, indicating that moisture content of redried seeds did not exert influence on sensitivity to thermal neutrons. The result is consistent with that reported by Caldecott (1955a) in thermal neutron irradiation of seeds in barley.

\section{Influence of moisture content of seeds on BAE}

The BAE values increased with increasing concentration of boric acid and the highest in $1600 \mu \mathrm{g} \cdot \mathrm{g}^{-1}$ in all moisture contents. The BAE value for $1600 \mu \mathrm{g} \cdot \mathrm{g}^{-1}$ in normal moisture content was 29.44. BAE for a given concentration of boric acid varied with moisture contents. Since the ${ }^{10} \mathrm{~B}$ content, originally existed or absorbed, of the embryo of the seed presoaked in a given concentration of boric acid solution, differs with moisture content of the re-dried seeds, BAE was plotted as a function of the content of ${ }^{10} \mathrm{~B}$ per $\mathrm{g}$ of tissue (Fig. 2) instead of the concentration of boric acid employed. From Eqs.(1) and (5), it follows;

$$
\begin{aligned}
\mathrm{BAE} & =D_{50 \mathrm{n}}{ }^{(0)} / D_{50 \mathrm{n}}{ }^{(1)} \\
& =\left(D_{50 \mathrm{~g}}{ }^{(0)}\left(K+e_{\mathrm{B}} d_{\mathrm{B}}^{(1)}\right)\right) /\left(D_{50 \mathrm{~g}}{ }^{(1)}\left(K+e_{\mathrm{B}} d_{\mathrm{B}}^{(0)}\right)\right) .
\end{aligned}
$$

Since the gamma-ray sensitivity did not change with boron addition, it can be assumed that $D_{50 \mathrm{~g}}{ }^{(1)}$ equals $D_{50 \mathrm{~g}}{ }^{(0)}$ for any concentration of boric acid and BAE is simplified as;

$$
\mathrm{BAE}=\left(K+e_{\mathrm{B}} d_{\mathrm{B}}^{(1)}\right) /\left(K+e_{\mathrm{B}} d_{\mathrm{B}}^{(0)}\right)=K_{l}+K_{2} d_{\mathrm{B}}{ }^{(1)}
$$

where $K_{l}=K /\left(K+e_{\mathrm{B}} d_{\mathrm{B}}{ }^{(0)}\right)$ and $K_{2}=e_{\mathrm{B}} /\left(K+e_{\mathrm{B}} d_{\mathrm{B}}{ }^{(0)}\right)$. Both $K_{l}$ and $K_{l}$ are constant irrespective of the amount of absorbed ${ }^{10} \mathrm{~B}$, because $e_{\mathrm{B}}$ did not change with boric acid concentration. Eq.(7) shows that BAE is a linear function of $d_{\mathrm{B}}$. From Eq.(3) and (4a), $d_{\mathrm{B}}$ is a linear function of $(1-w) t$ which is the amount of ${ }^{10} \mathrm{~B}$ per $\mathrm{g}$ of tissue. Therefore, BAE is linearly related to the amount of ${ }^{10} \mathrm{~B}$ (originally existed plus absorbed one) or of absorbed ${ }^{10} \mathrm{~B}$ per $\mathrm{g}$ of tissue. Naturally, if $d_{\mathrm{B}}{ }^{(1)}=$ $d_{\mathrm{B}}{ }^{(0)}$, then $\mathrm{BAE}=1$ from Eq. (7).

It was revealed that $\mathrm{BAE}$ values expressed by the regression coefficients in Eqs.(2a), (2b) and (2c) were lower in low and high moisture contents than in normal moisture content. The result suggests that, for getting high efficiency of boron enrichment in thermal neutron exposure, preparing the moisture content of the re-dried seeds to normal level ( $c a .10 \%)$ is effective. The lowering of BAE in high moisture content may be caused by increased interference of alpha particles with water molecules, as is often suggested by other researchers (Ikushima 1972b). But the same explanation is not valid for the decreased RBE in low moisture content.

Fig. 3 summarizes the results on the BAE values so far reported. To avoid the influence of the magnitude of enrichment of ${ }^{10} \mathrm{~B}$ in the boric acid or borate, BAE values were plotted as a function of concentration of ${ }^{10} \mathrm{~B}$ in a solution. The BAE values obtained in our present and previous experiments and those reported by Ichikawa (1975) are the highest among the data collected. The boron enrichment by Matsumura et al. (1963), Ikushima (1972b), and Nakai and Saito (1976) gave smaller values of BAE. The less effective boron enrichment in these experiments may be ascribed to different causes. Matsumura et al. (1963) immersed the seeds of Triticum monococcum for 2 days, and Ikushima (1972b) immersed the seeds of diploid, tetraploid, and hexaploid Triticum for $24 \mathrm{~h}$. They both did not redry the seeds after immersion, which might have lowered BAE. Nakai and Saito (1976) immersed rice seeds for $48 \mathrm{~h}$ and allowed the seeds to redry. Duration of immersion of the seeds might be too long for their plant material, and the start of germination process and change of metabolic condition during immersion of seeds (Takahashi 1960) might have reduced BAE. In the experiments by Nakai and Saito (1976), another cause is less effective absorption of boron by the embryo. They indicated that after immersing of rice seeds in 1000 and $4000 \mu \mathrm{g} \cdot \mathrm{g}^{-1}$ natural boric acid solution the embryo absorbed 25.6 and $110.0 \mu \mathrm{g} \cdot \mathrm{g}^{-1}$ boron, respectively, whereas in our previous experiment (Ukai et al. in press) immersing of barley seeds in 1600 and $4800 \mu \mathrm{g} \cdot \mathrm{g}^{-1}$ solution made the embryo absorb 172.9 and $417.9 \mu \mathrm{g} \cdot \mathrm{g}^{-1}$, respectively. The amount of absorption of boron per unit concentration of boric acid in the former was only about a forth or third that of the latter.

\section{Influence of moisture content of seed embryos on RBE of alpha particles}

The RBE values of alpha particles did not much vary 


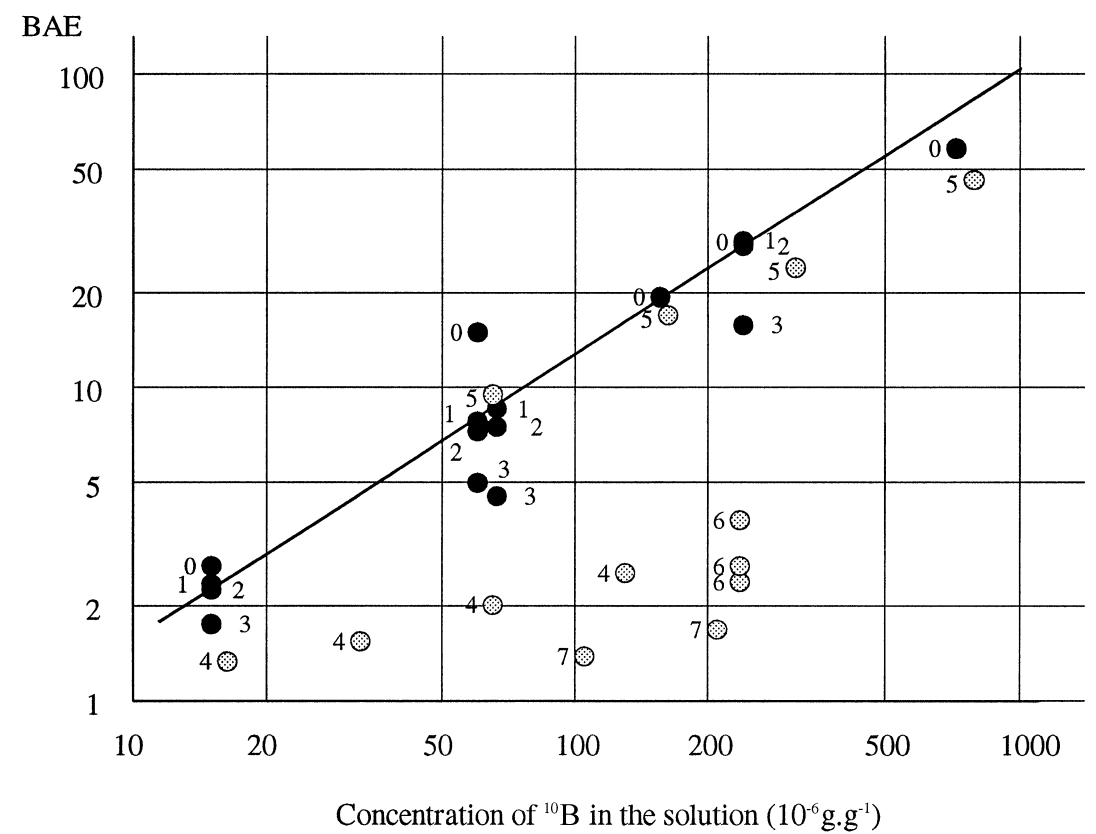

Fig. 3. Summarized results on boron addition effect (BAE) plotted against the concentration of ${ }^{10} \mathrm{~B}$ in the boric acid or borate solution. The solid circles represents the results of our present and the previous experiments, while the open circles the results reported by other researchers. The numbers attached to the circles stand for as follows; 0: normal moisture content in the previous experiment, 1: normal moisture content, 2: low moisture content, 3: high moisture content in the present experiment, 4: Nakai and Saito (1976), 5: Ichikawa (1975), 6: Ikushima (1972b), 7: Matsumura et al. (1963).

with boric acid concentrations or ${ }^{10} \mathrm{~B}$ content. However, the mean values of RBE over boric acid concentrations obviously varied with the moisture content of seed embryos. The estimated RBE values were 46.4, 37.4 and 17.0 for normal, low and high moisture contents, respectively. Both decrease and increase of water in seeds significantly lowered RBE $(\mathrm{P}<0.05)$.

Combining Eqs.(1) and (6) gives;

$$
\begin{aligned}
& e_{\mathrm{B}}^{(\mathrm{N})}=\left(\left(D_{50 \mathrm{~g}}{ }^{(\mathrm{N} 1)} / D_{50 \mathrm{n}}{ }^{(\mathrm{N} 1)}\right)\right. \\
& \left.-\left(D_{50 \mathrm{~g}}{ }^{(\mathrm{N} 0)} / D_{50 \mathrm{n}}{ }^{(\mathrm{N} 0)}\right)\right) /\left(d_{\mathrm{B}}{ }^{(\mathrm{N} 1)}-d_{\mathrm{B}}{ }^{(\mathrm{N} 0)}\right) \\
& =\left(\left(\mathrm{BAE}^{(\mathrm{N})} \cdot D_{50 \mathrm{~g}}{ }^{(\mathrm{N} 1)} / D_{50 \mathrm{n}}{ }^{(\mathrm{N} 0)}\right)\right. \\
& \left.-\left(D_{50 \mathrm{~g}}{ }^{(\mathrm{N} 0)} / D_{50 \mathrm{n}}{ }^{(\mathrm{N} 0)}\right)\right) /\left(d_{\mathrm{B}}{ }^{(\mathrm{N} 1)}-d_{\mathrm{B}}{ }^{(\mathrm{N} 0)}\right)
\end{aligned}
$$

where $\mathrm{N}$ stands for normal moisture content and 0 and 1 stand for the treatment with ${ }^{10} \mathrm{~B}$-non-enriched $\left(0 \mu \mathrm{g} \cdot \mathrm{g}^{-1}\right)$ and an enriched solution, respectively. As Table 1 shows, the sensitivity to gamma-rays did not change with the boric acid concentration, hence it can be assumed $D_{50 \mathrm{~g}}{ }^{(\mathrm{N} 1)}=D_{50 \mathrm{~g}}{ }^{(\mathrm{N} 0)}=$ $D_{50 \mathrm{~g}}{ }^{\mathrm{N})}$ where $D_{50 \mathrm{~g}}{ }^{(\mathrm{N})}$ represents mean values of $D_{50 \mathrm{~g}}$ values for normal moisture content. Therefore, it follows;

$$
e_{\mathrm{B}}^{(\mathrm{N})}=\left(D_{50 \mathrm{~g}}{ }^{(\mathrm{N})} / D_{50 \mathrm{n}}{ }^{(\mathrm{N} 0)}\right)\left(\mathrm{BAE}^{(\mathrm{N})}-1\right) /\left(d_{\mathrm{B}}{ }^{(\mathrm{N} 1)}-d_{\mathrm{B}}{ }^{(\mathrm{N} 0)}\right)
$$

The same equation holds for high moisture content as follows,

$$
e_{\mathrm{B}}{ }^{(\mathrm{H})}=\left(D_{50 \mathrm{~g}}{ }^{(\mathrm{H})} / D_{50 \mathrm{n}}{ }^{(\mathrm{H} 0)}\right)\left(\mathrm{BAE}^{(\mathrm{H})}-1\right) /\left(d_{\mathrm{B}}{ }^{(\mathrm{H} 1)}-d_{\mathrm{B}}{ }^{(\mathrm{H} 0)}\right)
$$

where $\mathrm{H}$ represents high moisture content. From the Eqs.(8) and (9), the ratio of RBE of alpha particles for high to normal moisture content for the treatment with a given concentration of boric acid solution is given by;

$$
\begin{aligned}
& e_{\mathrm{B}}{ }^{(\mathrm{H})} / e_{\mathrm{B}}{ }^{(\mathrm{N})}=\left(\mathrm{D}_{50 \mathrm{~g}}{ }^{(\mathrm{H})} / D_{50 \mathrm{~g}}{ }^{(\mathrm{N})}\right)\left(\mathrm{D}_{50 \mathrm{n}}{ }^{(\mathrm{N} 0)} / D_{50 \mathrm{n}}{ }^{(\mathrm{H} 0)}\right) \\
& \left(\left(\mathrm{BAE}^{(\mathrm{H})}-1\right) /\left(\mathrm{BAE}^{(\mathrm{N})}-1\right)\right) \\
& \left(\left(d_{\mathrm{B}}{ }^{(\mathrm{N} 1)}-d_{\mathrm{B}}{ }^{(\mathrm{N} 0)}\right) /\left(d_{\mathrm{B}}{ }^{(\mathrm{H} 1)}-d_{\mathrm{B}}{ }^{(\mathrm{H} 0)}\right)\right)
\end{aligned}
$$

Since $\mathrm{D}_{50 \mathrm{n}}{ }^{(\mathrm{N} 0)}$ nearly equals $D_{50 \mathrm{n}}{ }^{(\mathrm{H} 0)}$, the ratio $\mathrm{D}_{50 \mathrm{n}}{ }^{(\mathrm{N} 0) /}$ $D_{50 \mathrm{n}}{ }^{(\mathrm{H} 0)}$ can be assumed to be 1 .

$\left(d_{\mathrm{B}}{ }^{(\mathrm{N} 1)}-d_{\mathrm{B}}{ }^{(\mathrm{N} 0)}\right) /\left(d_{\mathrm{B}}{ }^{(\mathrm{H} 1)}-d_{\mathrm{B}}{ }^{(\mathrm{H} 0)}\right)$ is the ratio of the neutron energy absorbed by absorbed boron between normal and high moisture contents. $d_{\mathrm{B}}{ }^{(\mathrm{N} 0)}$ is negligible as compared with $d_{\mathrm{B}}{ }^{(\mathrm{N})}$, and $d_{\mathrm{B}}{ }^{(\mathrm{H} 0)}$ is negligible as compared with $d_{\mathrm{B}}{ }^{(\mathrm{H} 1)}$, hence the ratio $\left(d_{\mathrm{B}}{ }^{(\mathrm{N} 1)}-d_{\mathrm{B}}{ }^{(\mathrm{N} 0)}\right) /\left(d_{\mathrm{B}}{ }^{(\mathrm{H} 1)}-d_{\mathrm{B}}{ }^{(\mathrm{H} 0)}\right)$ can be approximated by $d_{\mathrm{B}}{ }^{(\mathrm{N} 1)} / d_{\mathrm{B}}{ }^{(\mathrm{H} 1)}$. From these facts, in the present experiment $e_{\mathrm{B}}{ }^{(\mathrm{H})} / e_{\mathrm{B}}{ }^{(\mathrm{N})}$ is given by;

$$
\begin{aligned}
e_{\mathrm{B}}{ }^{(\mathrm{H})} / e_{\mathrm{B}}{ }^{(\mathrm{N})} \cong & \left(\mathrm{D}_{50 \mathrm{~g}}{ }^{(\mathrm{H})} / D_{50 \mathrm{~g}}{ }^{(\mathrm{N})}\right) \\
& \left(\left(\mathrm{BAE}^{(\mathrm{H})}-1\right) /\left(\mathrm{BAE}^{(\mathrm{N})}-1\right)\right) /\left(d_{\mathrm{B}}{ }^{\left.(\mathrm{H} 1) / d_{\mathrm{B}}{ }^{(\mathrm{N} 1)}\right)}\right.
\end{aligned}
$$

Thus, the low RBE values in high moisture content of seeds can be ascribed to the three factors, i.e., the ratio of $D_{50 \mathrm{~g}}$, ratio of (BAE-1), and ratio of $d_{\mathrm{B}}{ }^{(1)}$ between high and normal moisture contents. From Eq. $(3 \mathrm{a})$, the ratio $\left(d_{\mathrm{B}}{ }^{(\mathrm{N} 1)_{-}}\right.$ $\left.d_{\mathrm{B}}{ }^{(\mathrm{N} 0)}\right) /\left(d_{\mathrm{B}}{ }^{(\mathrm{H} 1)}-d_{\mathrm{B}}{ }^{(\mathrm{H} 0)}\right)$ and $d_{\mathrm{B}}{ }^{(\mathrm{N} 0) / d_{\mathrm{B}}}{ }^{(\mathrm{H} 0)}$ equals $\left(1-\mathrm{w}^{(\mathrm{N})}\right) /\left(1-\mathrm{W}^{(\mathrm{H})}\right)$ where $\mathrm{w}^{(\mathrm{N})}$ and $\mathrm{w}^{(\mathrm{H})}$ represent normal and high moisture contents of the seed embryos, respectively. The mean values of $\mathrm{D}_{50 \mathrm{~g}}$ were $353 \mathrm{~Gy}$ in normal moisture content whereas $236 \mathrm{~Gy}$ in high moisture content (Table 1). The latter is $66.9 \%$ of the former. The (BAE-1) in the high moisture content was $65.1 \%$ of that of the normal moisture content as shown in the regression coefficients in Eqs.(2a) and (2c). The ratio $\left(1-\mathrm{w}^{(\mathrm{N})}\right) /\left(1-\mathrm{w}^{(\mathrm{H})}\right)$ is $(1-0.102) /(1-0.280)=1.243$. The ratio of the mean estimated $\mathrm{RBE}$ values of high to 
normal moisture content was $17.0 / 46.4=0.366$. This ratio nearly equals the value calculated according to Eq.(11) $0.669 \times 0.651 / 1.243=0.350$.

Contrary to the case of high moisture content, the ratio of RBE between low and normal moisture contents could not quantitatively be divided into three factors as shown in Eq.(11). The mean values of $\mathrm{D}_{50 \mathrm{~g}}$ were $353 \mathrm{~Gy}$ in normal moisture content whereas 365 Gy in low moisture content (Table 1). The latter is $103.4 \%$ of the former. (BAE-1) in the low moisture content was $87.7 \%$ of the normal moisture content as shown by the regression coefficients of Eqs. (2a) and $(2 \mathrm{~b})$. The ratio $\left(1-\mathrm{w}^{(\mathrm{N})}\right) /\left(1-\mathrm{w}^{(\mathrm{L})}\right)$ is $(1-0.102) /(1-0.0255)=$ 0.9215 where $^{(\mathrm{L})}$ represents low moisture content. The ratio of mean estimated RBE values of low to normal moisture content was $37.4 / 46.4=0.806$. This ratio is lower than the calculated value $1.034 \times 0.877 / 0.9215=0.984$. The reason for the discrepancy between the observed and calculated ratios is not clear.

\section{Influence of moisture content of seed embryos on RBE of protons}

Mean RBE values of protons were 39.4, 39.3 and 40.5 for normal, low and high moisture contents, respectively, showing no significant differences between moisture contents $(\mathrm{P}>0.05)$. Unlike RBE of alpha particles, RBE of protons does not seem to be influenced by moisture content of seed embryos, which means that emitted protons do not interfere with water molecules in the surrounding space in a cell. The reason for this is currently unclear, although a possible reason could be differences in the distribution within cells between boron and nitrogen atoms. A nitrogen atom is included in the structure of DNA and the histone protein of chromatin as an important component, whereas boron is preferentially concentrated in the cell-wall and associated with cell wall pectins (Hu and Brown 1994). Since boron atoms are distributed at some distance from biologically important targets, interference with water molecules would be greater for alpha particles emitted from boron atoms than for protons emitted from nitrogen atoms, which are included in the targets themselves.

In conclusion, moisture content of seed embryos of the re-dried seeds influences on the RBE of alpha particles but not on RBE of protons in thermal neutron exposures. The adjustment of moisture to normal content (about 10\%) is important to get a high value of both BAE and RBE of alpha particles.

\section{Acknowledgments}

Thanks are due to staff-members of the Research Reactor Institute, Kyoto Univ. particularly Dr. Tadatoshi Kikuchi for their great help in performing the neutron exposures and dosimetry. The authors acknowledge Hirotake Maruyama for his skilful technical assistance.

\section{Literature Cited}

Altman,P.L. and D.S.Ditmer (1972) Biology Data Book, $2^{\text {nd }}$ edn. Vol.1, Fed. Am. Soc. Exp. Biol. 2123 p.

Archambeau,J.O. (1971) The response of the skin of swine to increasing absorbed doses of the ${ }^{10} \mathrm{~B}(\mathrm{n}, \alpha)^{7} \mathrm{Li}$ reaction: Histologic and cytologic changes. Radiation Research 45: 137-144.

Bender,M.A. (1970) Neutron-induced genetic effects: A review. Radiation Botany 10: 225-247.

Bruggemann,E., K. Handwerger, C. Essex and G.Storz (1996) Analysis of fast neutron-generated mutants at the Arabidopsis thaliana HY4 locus. Plant J. 10: 755-760.

Caldecott,R.S. (1955a) Effects of ionizing radiations on seeds of barley. Rad. Res. 2: 339-350.

Caldecott, R.S. (1955b) Effects of hydration on X-ray sensitivity in Hordeum. Rad.Res. 3: 316-330.

Conger,A.D. and N.H.Giles (1950) The cytogenetic effect of slow neutrons. Genetics 35: 397-419.

Davis,M.A., J.B.Little, K.M.M.S. Ayyangar and A.R. Reddy (1970) Relative biological effectiveness of the ${ }^{10} \mathrm{~B}(\mathrm{n}, \alpha)^{7} \mathrm{Li}$ reaction in Hella cells. Rad. Res. 43: 534-553.

Ehrenberg,L. (1955a) The radiation induced growth inhibition in seedlings. Botanika Notiser 108: 184-215.

Ehrenberg,L. (1955b) Factors influencing radiation induced lethality, sterility and mutation in barley. Hereditas 41: 123-146.

$\mathrm{Hu}, \mathrm{H}$. and P.H.Brown (1994) Localization of boron in cell walls of squash and tobacco and its association with pectin. Plant Physiol. 105: 681-689.

Ichikawa,S. (1975) The biological effects of heavy particles from the nuclear reaction of ${ }^{10} \mathrm{~B}(\mathrm{n}, \alpha)^{7} \mathrm{Li}$ in diploid wheat seeds containing widely different ${ }^{10} \mathrm{~B}$ contents. Annual Report of the Research Reactor Inst. Kyoto Univ. 8: 32-43.

IAEA (1974) Biological Effects of Neutron Irradiation. IAEA, Vienna, p. 482 .

Ikushima,T. (1972a) Relative biological effectiveness of $14.1 \mathrm{MeV}$ neutrons for somatic mutations induced in the diploid oat seeds presoaked in water. Jpn. J. Genet. 47: 265-275.

Ikushima,T. (1972b) Relative biological effectiveness of heavy particles from the reaction ${ }^{10} \mathrm{~B}(\mathrm{n}, \alpha)^{7} \mathrm{Li}$ for cytogenetic effects in a ploidy series of the genus Triticum. Jpn. J. Genet. 47: 401-410.

Katayama,T. and T.Nagamatsu (1966) Radiosensitivity in plant I. Relation between the water content of some crop seeds and their sensitivity to different doses of X-rays and gamma-rays. Jpn. J. Breed. 16: 77-82.

Kawai,T. and H.Sato (1966) Some factors modifying the effects of radiation in seed treatment in rice. In: "Mutation in Plant Breeding", IAEA, pp. 151-171.

Li,X., Y.Song, K.Century, S.Straight, P.Ronald, X.Dong, M.Lassner and Y. Zhang (2001) A fast neutron deletion mutagenesis-based reverse genetics system for plants. Plant J. 27: 235-242.

Li,X., M.Lassner and Y.Zhang (2002) Deleteagene: a fast neutron deletion mutagenesis-based gene knockout system for plants. Comparative and Functional Genomics 3: 158-160.

Matsumura,S., S.Kondo and T.Mabuchi (1963) Radiation genetics in wheat VIII. The RBE of heavy particles from ${ }^{0} \mathrm{~B}(\mathrm{n}, \alpha)^{7} \mathrm{Li}$ reaction for cytogenetic effects in eincorn wheat. Radiation Botany 3: 29-40.

Myttenaere,C., Ph. Bourdeau, G.Helcke and M.Masset (1965) Radiosensitivity of rice seed in relation to water content and free radicals. Rad. Bot. 5: 443-451.

Nakai,H. and M. Saito (1976) The contribution of boron to radiobiological effects of thermal neutrons in rice. Environ. Experi. Bot. 
16: $267-275$.

Takahashi,N. (1960) The pattern of water absorption in rice seed during the germination I. The relationship between the pattern and the germination velocity. Jpn. J. Crop Sci. 29: 1-3.

Ukai,Y. (1969) Studies on varietal differences in radiosensitivity in rice $V$. Radiosensitivity in irradiation with different modifying factors. Jpn. J. Breed. 19: 293-301.

Ukai,Y. (1986) Maximum mutation frequency in gamma-ray and ther- mal neutron exposures in barley. Gamma Field Symposia 25: 5572.

Ukai,Y. (2006) Effectiveness and efficiency of mutagenic treatments. Gamma Field Symposia 45: 1-14.

Ukai,Y., A.Yamashita and H.Takaki (2009) Simultaneous estimation of relative biological effectiveness of alpha particles and protons in thermal neutron exposure of barley (Hordeum vulgare L.) seeds. Breed. Sci. 59: 187-193. 